\title{
SPRAWOZDANIA
}

\section{OGÓLNOPOLSKIE SYMPOZJA RZYMIANISTÓW}

Już od kilkunastu lat Katedra Prawa Rzymskiego i Antycznego Uniwersytetu Warszawskiego wraz z Komitetem Nauk o Kulturze Antycznej PAN organizuje kilka razy do roku ogólnopolskie zebrania rzymianistów. Pracownicy naukowi z poszczególnych ośrodków w Polsce przybywają na Wydział Prawa i Administracji UW, by w zaciszu Biblioteki Papirologii, Prawa Rzymskiego i Antycznego im. R. Taubenschlaga spotkać się w zaprzyjaźnionym gronie i wymienić się poglądami na temat prawa rzymskiego. Każde zebranie jest okazją do przedyskutowania bieżących spraw związanych z dydaktyką oraz refleksji nad nauczaniem prawa rzymskiego w przyszłości. Są to cenne dyskusje, tym bardziej że uczestniczą w nich przedstawiciele różnych ośrodków akademickich w Polsce, co daje możliwość uzyskania szerszego spektrum problemów.

Ważna w warszawskich spotkaniach jest również ich strona naukowa. Podczas każdego zebrania wygłaszane są bowiem referaty z zakresu prawa rzymskiego i antycznego.

W bieżącym 2012 roku Katedra Prawa Rzymskiego i Antycznego UW zorganizowała już trzy ogólnopolskie spotkania rzymianistów. Pierwsze odbyło się 21 lutego. Referaty wygłosili wówczas dr Marek Sobczyk z Uniwersytetu Mikołaja Kopernika w Toruniu i dr Maria Nowak z UW. Referat dr. M. Sobczyka był poświęcony Zwrotowi świadczenia spetnionego w zamierzonym celu, który nie zostat osiagnięty ('condictio ob rem dati'). Natomiast dr M. Nowak mówiła o Strukturze testamentu rzymskiego w okresie późnej starożytności.

Pierwsze wiosenne zebranie na Uniwersytecie Warszawskim miało miejsce 16 kwietnia. Spotkanie rozpoczął prof. José Luis Alonso 
pracujący na Wydziale Historycznym Uniwersytetu Warszawskiego i Universidad del País Vasco, San Sebastian, wygłoszając w języku włoskim referat zatytułowany Ontologia giuridica. Omawiane przez niego zagadnienie od lat cieszy się wśród rzymianistów i historyków starożytności dużym zainteresowaniem, w związku z czym należy obecnie do jednego z lepiej zbadanych problemów w nauce o prawie antycznym, jednak w pewnych aspektach wciąż budzi pytania. Na nie właśnie starał się odpowiedzieć prof. J. Luis Alonso podczas swojego wystapienia, które zebranym wydało sie tym bardziej interesujące, że oparte było na licznych przykładach praktycznych zaczerpniętych z Digestów justyniańskich. Drugim prelegentem tego dnia była dr Anna Plisecka z Uniwersytetu Adama Mickiewicza w Poznaniu, ktorej wystąpienie dotyczące Tłumaczenia konstytucji cesarskich (I-III) wywołało żywą dyskusję. Zebrani zastanawiali się w szczególności nad wiarygodnością dokonanych w przeszłości tłumaczeń poszczególnych konstytucji, na które powoływała się referentka w swoim wystąpieniu.

Po raz trzeci w tym roku rzymianiści polscy mieli okazję spotkać się 11 czerwca. Z referatami przyjechali: dr hab. Renata Świrgoń-Skok z Uniwersytetu Rzeszowskiego oraz dr Maciej Jońca z Katolickiego Uniwersytetu Lubelskiego Jana Pawła II. Wystąpienie prof. R. Świrgoń-Skok było poświęcone problematyce Obywatelstwa niewolnika ustanowionego spadkobierca $w$ testamencie rzymskim. Prelegentka zastanawiała się nad wymogami decydującymi o dopuszczalności ustanowienia niewolnika dziedzicem w testamencie sporządzonym przez Rzymianina, a także nad skutkami takiego zapisu. Szczególny nacisk położyła na problematykę nabycia obywatelstwa przez niewolnika wyzwolonego w sposób formalny, zwłaszcza na drodze testamentu. Dr M. Jońca mówił natomiast na temat Prowiantu dla prokonsula. Uwagi na marginesie marginesu do D. 1.16.6.3 w Kórnickim rękopisie Digestum vetus. Punktem wyjściowym jego referatu był termin ' $x e$ nia', oznaczający dary (podarunki) dla namiestnika prowincji. Referent starał się odpowiedzieć na pytanie, co mogło stanowić owe dary, a więc czy tylko produkty spożywcze i płody rolne, czy także kwoty pieniędzy. Prelekcję dr. M. Jońcy ubarwił pokaz slajdów. Oba refera- 
ty sprowokowały długa dyskusję, w której głos przewodni należał do prof. Marka Kuryłowicza z Uniwersytetu Marii Curie-Skłodowskiej w Lublinie. Ostatni problem, który nieoczekiwanie pojawił się tego dnia, a który najbardziej zainteresował młodszych pracowników naukowych zebranych w bibliotece im. R. Taubenschlaga, dotyczył zasad uzyskiwania stopnia doktora habilitowanego według nowego porządku. Choć kwestia ta, zapewne z powodu wciąż budzącej wątpliwości procedury, nikogo z zebranych nie napawała optymizmem, jednak wszyscy rozstali się w dobrych humorach, na co niewatpliwie wpływ miała perspektywa zbliżających się wakacji. Kolejne spotkanie odbędzie się już w nowym roku akademickim.

Renata Kamińska*

* Uniwersytet Kardynała Stefana Wyszyńskiego. 